\title{
The AfD's Winning Formula - No Need for Economic Strategy Blurring in Germany
}

\begin{abstract}
Western European Populist Radical Right Parties (PRRPs) have addressed the dispersed socio-economic status of their electorates by blurring their economic positioning. This contribution analyses the rise of the German PRRP Alternative für Deutschland (AfD) between 2013 and 2017 and the role of its economic policy platform. In contrast to its European peers, the AfD shows few signs of economic strategy blurring. The party offers clear antiredistribution policies that are matched by AfD voters' preferences: even the least affluent AfD supporters have stronger preferences for lower redistribution than the most affluent non-AfD supporters. For AfD supporters with lower socio-economic positions this means that they support economic policies that are against their economic interests. Extreme authoritarian cultural policies spiced up with criticism of the establishment and combined with a general opposition to redistribution can be identified as the AfD's winning formula. Within the Western European PRRP party family, this winning formula directed at supporters with lower socioeconomic positions constitutes an exception.
\end{abstract}

The Western European party family of Populist Radical Right Parties has gone through a vivid transformation. ${ }^{1}$ Particularly, PRRPs' economic positioning has become an object of study as they shift away from neo-liberal economic policy platforms and as the parties increasingly attract an electorate with lower socio-economic status. ${ }^{2}$ Today, the Western European political landscape holds a variety of strategies for PRRP's potential economic policy. These range from the French Front National model of endorsing pro-welfare policies to the Swiss Peoples

(c) The Author(s) 2020. Open Access: This article is distributed under the terms of the Creative Commons Attribution 4.0 International License (https://creativecommons.org/licenses/by/4.0/).

Open Access funding provided by ZBW - Leibniz Information Centre for Economics.

1 C. Mudde: Populist Radical Right Parties in Europe, New York 2007, Cambridge University Press.

2 E. Ivarsflaten: The vulnerable populist right parties: No economic realignment fuelling their electoral success, in: European Journal of Political Research, Vol. 44, No. 3, 2005, pp. 465-492; A. Afon so, L. Renwald: The Changing Welfare State Agenda of Radical Right Parties in Europe, in: B. Palier, P. Manow (eds.): Electoral Politics and Welfare State Reforms, Oxford 2018, Oxford University Press.

Matthias Diermeier, German Economic Institute (IW), Cologne; and University of Duisburg-Essen, Germany.
Party's well-known 'winning formula' of 'right' cultural positions and a neoliberal economic policy. Applying more nuanced strategies, PRRPs persuade their supporters by subsuming the economic dimension under their cultural core position or by blurring its economic policy. ${ }^{3}$ In this regard, the German newcomer party Alternative für Deutschland (AfD) appears to be a prime object of study as it goes through a similar transformation, albeit in fastforward between 2013 and 2017.4

\section{PRRPs in a multidimensional context}

In contrast to the belief that party competition is mostly carried out along unidimensional conflict lines on the economic dimension, scholars following Riker's heresthetics stress the importance of different dimensions, including non-economic issues as well as party competition, over dimensional salience. ${ }^{5}$ Rovny and Edwards note that "political competition is primarily a struggle over dimensionality, it does not merely occur along issue dimensions but also over their content" - with special incentives for niche

3 A. Elias, E. Szöcsik, C.I. Zuber: Position, selective emphasis and framing, in: Party Politics, Vol. 21, No. 6, 2015, pp. 839-850; J. Rovny: Where do radical right parties stand? Position blurring in multidimensional competition, in: European Political Science Review, Vol. 5, No. 1, 2013, pp. 1-26.

4 K. Arzheimer, C.C. Berning: How the Alternative for Germany (AfD) and their voters veered to the radical right, 2013-2017, in: Electoral Studies, Vol. 60, 2019.

5 W.H. Riker: The Art of Political Manipulation, New Haven 1986, Yale University Press. 
parties to introduce secondary, non-economic issues. ${ }^{6}$ Norris and Inglehart find a predominance of the cultural dimension and christen the rise of PRRPs in Western democracies a cultural backlash:7 an uprising against the diffusion of progressive values and the approval of migration, channelled through nativist, authoritarian and populist radical right parties. ${ }^{8}$

Regarding the welfare policy platforms of PRRPs, Kitschelt and McGann sketch the 'winning formula' as a neo-liberal economic agenda with an authoritarian profile in the cultural and political dimension. ${ }^{9}$ This formula has become highly controversial as the heterogeneity of Western European PRRPs is carved out in bits and pieces. ${ }^{10}$ First, PRRPs are considered, to a certain degree, Anti-Party Parties (APPs) that discredit the political system as such. ${ }^{11}$ If PRRPs were to opportunistically endorse whichever goal appeals to their electorate, they would attract more protest voters than issue voters, resulting in a generally lower importance of actual issue positioning. ${ }^{12}$ Second, some PRRPs - e.g. the Front National under Marine Le Pen - meet lower socio-economic positions of their electorates programmatically with a shift to pro-welfare positions. ${ }^{13}$ Third, a centrist convergence of PRRPs in the economic policy dimension during the 1990s and 2000s can be observed - e.g. in Belgium and the Netherlands - with PRRPs proposing an absurd socio-economic agenda of economic liberalism and a welfare state. ${ }^{14}$ In this context, Mudde and Ivarsflaten stress the

6 J.Rovny, E.E. Edwards: Struggle over Dimensionality: Party Competition in Western and Eastern Europe, in: East European Politics \& Societies, Vol. 26, No. 1, 2012, pp. 56-74, here p. 56.

7 P. Norris, R. Inglehart: Cultural Backlash: Trump, Brexit, and Authoritarian Populism, Cambridge 2019, Cabridge University Press.

8 C. Mudde: Populist Radical..., op. cit.

9 H. Kitschelt, A. McGann: The Radical Right in Western Europe: A Comparative Analysis, Ann Arbor 1995, The University of Michigan Press.

10 See M. Rooduijn: What unites the voter bases of populist parties? Comparing the electorates of 15 populist parties, in: European Political Science Review, Vol. 10, No. 3, 2018, pp. 351-368 for a discussion of the differences of Western European PRRPs' electorates and their redistribution preferences. See S. Otjes, G. Ivaldi, A.R. Jupskås, O. Mazzoleni: It's not Economic Interventionism, Stupid! Reassessing the Political Economy of Radical Right-wing Populist Parties, in: Swiss Political Science Review, Vol. 7, No. 2, 2018, p. 271 for current empirical evidence of the diversity of Western European PRRPs' economic agenda.

11 T. Pogunke, S.E. Scarrow: The politics of anti-party sentiment: Introduction1, in: European Journal of Political Research, Vol. 29, No. 3, 1996, pp. 257-262.

12 K. Deschouver: Political parties and democracy: A mutual murder?, in: European Journal of Political Research, Vol. 29, No. 3, 1996, pp. 263-278.

13 A. Afonso, L. Renwald, op. cit; Z. Lefkofridi, E. Michel: The Electoral Politics of Solidarity, in: K. Banting, W. Kymlicka (eds.): The Strains of Commitment, 2017, Oxford University Press.

14 C. Mudde: Populist Radical..., op. cit. For Belgium and the Netherlands, see S.L. de Lange: A New Winning Formula?, in: Party Politics, Vol. 13 , No. 4, 2007, pp. 411-435. welfare chauvinist character of PRRP's economic policy platforms and find that PRRPs subsume their economic policy under a cultural core issue, in order to address dispersed preferences for redistribution - e.g. in Denmark and France. ${ }^{15}$ Fourth, Rovny claims that radical 'right' parties deliberately cloud their positioning in the economic dimension as they focus on cultural issues, allowing them to attract an electorate with heterogeneous redistribution and homogeneous cultural preferences. ${ }^{16}$ Finally, the old winning formula of anti-migration and anti-redistribution attitudes seems to be a driver of PRRP support in Switzerland and, to a lesser degree, in Norway. ${ }^{17}$ However, in contrast to most Western European PRRPs, the Swiss People's Party and the Norwegian Progress Party still attract a rather affluent electorate.

Following Elias et al.'s theoretical elaboration of the outlined bi-dimensional setting, parties can either choose to reveal a position in both dimensions (bi-dimensionality) or ignore one dimension entirely (uni-dimensionality). ${ }^{18}$ Also, parties may deliberately blur one dimension (blurring) or subsume it under the other dimension (subsuming). Depending on the characteristics of the respective party system and dimensional salience relation, this theoretical framing describes the possible strategy space for PRRPs.

\section{Shaking up the Party System: AfD}

The German party system may be considered a prime example of the described theoretical strategy setting. It can be outlined through a socio-economic cleavage over market freedom and state interventionism and a cultural cleavage between a libertarian and an authoritarian extreme. ${ }^{19}$ Also, polarisation between political parties increased significantly during the 2013 and 2017 election periods. ${ }^{20}$ Characterised as a two party-dominated political system, the decade-long decay of the election share of the social democratic SPD and the conservative CDU/ CSU is mirrored by a shift to the left of the entire party

15 See C. Mudde: Extreme right parties in Eastern Europe, in: Patterns of Prejudice, Vol. 34, No. 1, 2000, pp. 5-27; and S. Otjes et al., op. cit. Note popular definition of PRRPs' 'thin ideology' by C. Mudde: Populist Radical..., op. cit. misses a clear definition of the economic agenda.

16 See J. Rovny: Where do radical..., op. cit.; and Z. Somer-Topcu: Everything to Everyone: The Electoral Consequences of the BroadAppeal Strategy in Europe, in: American Journal of Political Science, Vol. 59, No. 4, 2015, pp. 841-854; A. Afonso, L. Renwald, op. cit.

17 M. Rooduijn, op. cit.

18 A. Elias, E. Szöcsik, C.I. Zuber, op. cit.

19 O. Niedermayer: Von der Zweiparteiendominanz zum Pluralismus: Die Entwicklung des deutschen Parteiensystems im westeuropäischen Vergleich, in: Politische Vierteljahrsschrift, Vol. 51, No. 1, 2010, pp. 1-13.

20 K.-R. Korte, D. Michels, J. Schoofs, N. Switek, K. Weissenbach: Parteiendemokratie in Bewegung, 2018, Nomos. 
system. ${ }^{21}$ Traditionally leaving potential PRRPs little room to manoeuvre, ${ }^{22}$ the CDU/CSU has gradually converged to centre-right positions since the 1990s, leaving a 'representational gap' on the far right of the cultural party competition dimension. ${ }^{23}$

Today, this far-right void is successively absorbed by the AfD. Established in 2013, the party's founding father, professor of economics Bernd Lucke, initially designed a single-issue Eurosceptic party ${ }^{24}$ dominated by its liberal, ${ }^{25}$ ordoliberal $^{26}$ or neo-liberal ${ }^{27}$ economic policy platform. During this founding period, the party attracted a particularly affluent and highly educated electorate. ${ }^{28}$ The party's first manifestos lack clear nativist and populist elements that are typical of the cultural policy positioning of PRRPs. ${ }^{29}$

After a tough factional struggle, the AfD's positioning in the cultural dimension was significantly radicalised by the national conservative wing having sacked Lucke as a spokesperson in July 2015. Scholars describe the postLucke programmatic adjustments as a shift to an antimigration party ${ }^{30}$ or a populist right-wing party. ${ }^{31}$ During this radicalisation period, the party's important social media communication focused more and more on the topics

21 O. Niedermayer: Von der Zweiparteiendominanz..., op. cit.

22 S. Bornschier: Cleavage Politics and the Populist Right: The New Cultural Conflict in Western Europe, Philadelphia, PA 2010, Temple University Press.

23 K.-R. Korte, D. Michels, J. Schoofs, N. Switek, K. Weissenbach, op. cit., p. 206; D. Art: The AfD and the end of containment in Germany, in: German Politics and Society, Vol. 36, No. 2, 2018, pp. $76-86$

24 R. Schmitt-Beck: The 'Alternative für Deutschland in the Electorate': Between Single-Issue and Right-Wing Populist Party, in: German Politics, Vol. 26, No. 1, 2017, pp. 124-148.

25 J. Schärdel: Vom euroskeptischen Herausforderer zur rechtsextremen Gefahr? Eine Untersuchung der regionalen Berichterstattung über die AfD in neun deutschen Landtagswahlkämpfen, in: Zeitschrift für Parlamentsfragen, Vol. 48, No. 1, 2017, pp. 76-101.

26 S.T. Franzmann: Calling the Ghost of Populism: The AfD's Strategic and Tactical Agendas until the EP Election 2014, in: German Politics, Vol. 25, No. 4, 2016, pp. 457-479.

27 J. Rosenfelder: Die Programmatik der AfD: Inwiefern hat sie sich von einer primär euroskeptischen zu einer rechtspopulistischen Partei entwickelt?, in: Zeitschrift für Parlamentsfragen, Vol. 48, No. 1, 2017, pp. 123-140.

28 O. Niedermayer, J. Hofrichter: Die Wählerschaft der AfD: Wer ist sie, woher kommt sie und wie weit rechts steht sie?, in: Zeitschrift für Parlamentsfragen, Vol. 47, No. 2, 2016, pp. 267-285.

29 K. Arzheimer: The AfD: Finally a Successful Right-Wing Populist Eurosceptic Party for Germany?, in: West European Politics, Vol. 38, No. 3, 2015, pp. 535-556; O. Nied erm ay er: Eine neue Konkurrentin im Parteiensystem? Die Alternative für Deutschland, in: O. Niedermayer (ed.): Die Parteien nach der Bundestagswahl 2013, Wiesbaden 2015, Springer, pp. 175-207.

30 O. Niedermayer, J. Hofrichter, op. cit.

31 N. Berbuir, M. Lewandowsky, J. Siri: The AfD and its Sympathisers: Finally a Right-Wing Populist Movement in Germany?, in: German Politics, Vol. 24, No. 2, 2015, pp. 154-178; J. Rosenfelder, op. cit. of migration and Islam. ${ }^{32}$ The AfD's gradual development into a nationwide competitive PRRP peaked with its historical success at the federal level in 2017, when the party won $12.6 \%$ of the votes, thus abruptly ending the longterm absence of a German PRRP. ${ }^{33}$ The party's classification by the public ${ }^{34}$ and the media ${ }^{35}$ moved to the 'right' accordingly. At the same time, AfD supporters kept their strong homogeneity in the cultural dimension, e.g. in their opposition to migration. ${ }^{36}$

The programmatic transformation has been accompanied by socio-economic changes within the AfD's support groups. Support from groups with lower socio-economic status, especially in Eastern Germany and within the working class, increased while support from high-income groups decreased. ${ }^{37}$ Accordingly, voter migration to the AfD differs with the incumbency on the regional level and comes from the Left party in Eastern Germany, from the CDU in major cities in Eastern German, from the CSU in Bavaria and the SPD in the Ruhr area. ${ }^{38}$ In contrast to former radical right-wing parties in Germany, the mobilisation of a certain traditional left-leaning electorate represents a unique feature of the AfD..$^{39}$ The AfD manages to attract a diverse electorate and mobilises non-voters as well as voters of several established parties. ${ }^{40}$ Where-

32 K. Arzheimer, C.C. Berning, op. cit.

$33 \mathrm{~S}$. Bornschier: Why a right-wing populist party emerged in France but not in Germany: cleavages and actors in the formation of a new cultural divide, in: European Political Science Review, Vol. 4, No. 1, 2012, pp. 121-145; O. Niedermayer: Von der Zweiparteiendominanz..., op. cit.

34 K. Bergmann, M. Diermeier: Die AfD: Eine unterschätzte Partei Soziale Erwünschtheit als Erklärung für fehlerhafte Prognosen, in: IW Report, No. 7, 2017.

35 J. Schärdel, op. cit.

36 H. Lengfeld: Die „Alternative für Deutschland“: eine Partei für Modernisierungsverlierer?, in: KZfSS Kölner Zeitschrift für Soziologie und Sozialpsychologie, Vol. 69, No. 2, 2017, pp. 209-232; T. Sc hwarzbözl, M. Fatke: Außer Protesten nichts gewesen? Das politische Potenzial der AfD, in: Politische Vierteljahresschrift, Vol. 57, No. 2, 2016 , pp. 276-299.

37 K. Bergmann, M. Diermeier, J. Niehues: Ein komplexes Gebilde. Eine sozio-ökonomische Analyse des Ergebnisses der AfD bei der Bundestagswahl 2017, in: Zeitschrift für Parlamentsfragen, Vol. 49, No. 2, 2018, pp. 243-264; K. Brenke, A. Kritikos: Wählerstruktur im Wandel, in: DIW Wochenbericht, No. 29, 2017; I. Bieber, S. Roßteutscher, P. Scherer: Die Metamorphosen der AfD-Wählerschaft: Von einer euroskeptischen Protestpartei zu einer ( $r$ echten Alternative?, in: Politische Vierteljahrsschrift, Vol. 59, 2018, pp. 433-461.

$38 \mathrm{~J}$. Olsen: The left party and the AfD: Populist Competitors in Eastern Germany, in: German Politics and Society, Vol. 36, No. 1, 2018, pp. 70-83; K. Bergmann, M. Diermeier, J. Niehues, 2008, op. cit.; L. Berg, A. Zick (ed.): Rechtspopulismus, soziale Frage \& Demokratie: S. Kurtenbach: Räumliche Aspekte des Rechtspopulismus, FGW-Studie, No. 1, Düsseldorf 2019.

39 M. Klein, F. Heckert, Y. Peper: Rechtspopulismus oder rechter Verdruss?, in: KZfSS Kölner Zeitschrift für Soziologie und Sozialpsychologie, Vol. 38, 2018, p. 535.

40 M. Hansen, J. Olsen: Flesh of the Same Flesh: A Study of Voters for the Alternative for Germany (AfD) in the 2017 Federal Election, in: German Politics, Vol. 28, No. 1, 2019, pp. 1-19. 
as the anti-establishment and anti-migration platforms clearly appeal to AfD supporters, the role of economic policies in the second period seems much less clear. The party itself identifies its economic policy as a potential spirit of discord in a strategy paper for the federal election in 2017:

With regard to so far non-decisive topics (this holds especially for economic and welfare policy), particular attention has to be paid to the fact that the AfD's electorate is not divided. Whereas parts of the bourgeoisie with a liberal-conservative mindset on the one hand and the working-class and the unemployed on the other hand hold similar views on topics such as Euro/ Europe, security, migration/Islam, democracy, national identity or genderism, differences can come up on questions such as tax equity, the pension level, health security contributions, rent control or unemployment security. [...] If this is not possible, cross references between core topics and presumably dividing topics have to be drawn. ${ }^{41}$

Anecdotal evidence shows that these strategic considerations are met by proposing welfare chauvinist policies subsuming the economic dimension in line with Ivarsflaten: ${ }^{42}$ Mirroring a broad increase of welfare chauvinism in Germany, ${ }^{43}$ the AfD faction from Thuringia demands higher redistribution and a 'citizens pension' - a pension increase for which only German citizens would be eligible. ${ }^{44}$ However, the party also endorses a pro-welfare positioning comparable to the Front National in France:45 Far-right faction leader Björn Höcke continues to call the AfD 'the party of social justice', ${ }^{46}$ demanding 'patriotism of solidarity' and even supporting the foundation of right-wing unions like the organisation 'Alarm'. ${ }^{47}$ On the contrary, scholars supporting the APP theory stress the AfD voters' protest characteristics and neglect the importance of actual issue positioning - particularly regarding economic policy. ${ }^{48}$ Schwarzbözl und Fatke claim "the AfD

41 Own translation from: Alternative für Deutschland: Demokratie wiederherstellen Dem Volk die Staatsgewalt zurückgeben: Die Strategie der AfD für das Wahljahr 2017, 2016.

42 E. Ivarsflaten, op. cit.

43 P. Marx, E. Naumann: Do right-wing parties foster welfare chauvinistic attitudes? A longitudinal study of the 2015 'refugee crisis' in Germany, in: Electoral Studies, Vol. 52, 2018, pp. 111-116.

44 AfD Fraktion im Thüringer Landtag: Es geht um Wertschätzung: Ein Konzept der AfD-Fraktion im Thüringer Landtag, 2018.

45 A. Afonso, L. Renwald, op. cit.

46 R. Hank: Nationalsoziale Alternative, in: Frankfurter Allgemeine Sonntagszeitung, 15 July 2018.

47 A. Schmelcher: National und sozial, in: Frankfurter Allgemeine Sonntagszeitung, 3 November 2019, No. 44; P. Marx, E. Naumann, op. cit.

48 S.T. Franzmann (ed.): Parteien und die Politisierung der Europäischen Union, 2018; I. Bieber, S. Roßteutscher, P. Scherer, op. cit. electorate represents a group of people that is particularly coherent with regard to cultural conflicts, in contrast it is rather incoherent with regard to economic conflicts". ${ }^{49}$ Opposingly, Hansen and Olsen find that "AfD voters were in the mainstream [...] in terms of their attitudes towards efforts to reduce inequality and the role of the welfare state". ${ }^{50}$ Finally, Goerres et al. provide evidence for the old Kitschelt and McGann 'winning formula': In their analysis, AfD supporters have particularly strong anti-redistribution preferences comparable with the PRRP electorates in Switzerland or Norway. ${ }^{51}$ Such a combination of 'right' cultural and economic preferences within the electorate would enable the party to provide a clear bi-dimensional positioning with no need for blurring.

\section{Data and measurement}

In order to analyse AfD's comparative positioning, the German party system's supply side in the economic and cultural dimensions for the legislative period between 2013 and 2017, the 2014 Chapel Hill Expert Surveys (CHES) and the 2017 CHES FLASH survey can be used. The CHES provides an operationalisation of the economic 'left-right' and cultural libertarian post-materialist dimension on an 11-point scale. For Germany, the party positioning is assessed by 13 experts in 2014 and 15 experts in 2017. Scholars have applied the standard deviation of these experts' judgements to proxy the degree of strategy blurring. ${ }^{52}$

In order to evaluate the success of the party's strategies, the perceived party positioning by the German electorate needs to be examined under the consideration of the electorate's own dimensional policy preferences and socio-economic control variables. For the legislative period between 2013 and 2017, several waves of the German Longitudinal Election Study (GLES) representative Longterm Online Tracking as well as the GLES pre- and postelection 2017 waves contain the relevant data including economic and cultural 'right-left' economics on an 11-point scale. In order to control for APP characteristics

49 T. Schwarzbözl, M. Fatke, op. cit., p. 289.

50 M. Hansen, J. Olsen, op. cit., 2019, p. 15.

51 A. Goerres, D.C. Spies, S. Kumlin: The Electoral Supporter Base of the Alternative for Germany, in: Swiss Political Science Review, Vol. 21, No. 4, 2018, p. 617. See also H. Kits chelt, A. McGann, op. cit., 1995

52 J. Rovny: Who emphasizes and who blurs? Party strategies in multidimensional competition, in: European Union Politics, Vol. 13, No. 2, 2012, pp. 269-292; J. Rovny: Where do radical..., op. cit.; B. Palier, P. Manow (eds.): Electoral Politics and Welfare State Reforms, Oxford 2018, Oxford University Press; K.J. Han, op. cit.; A. Afonso, L. Renwald, op. cit. See web Appendix of J. Rovny: Who emphasizes..., op. cit. for several tests approving the use of CHES-based standard deviations as a measurement of strategy blurring. 
Figure 1

Experts' issue positioning of German parties in the economic and cultural dimension
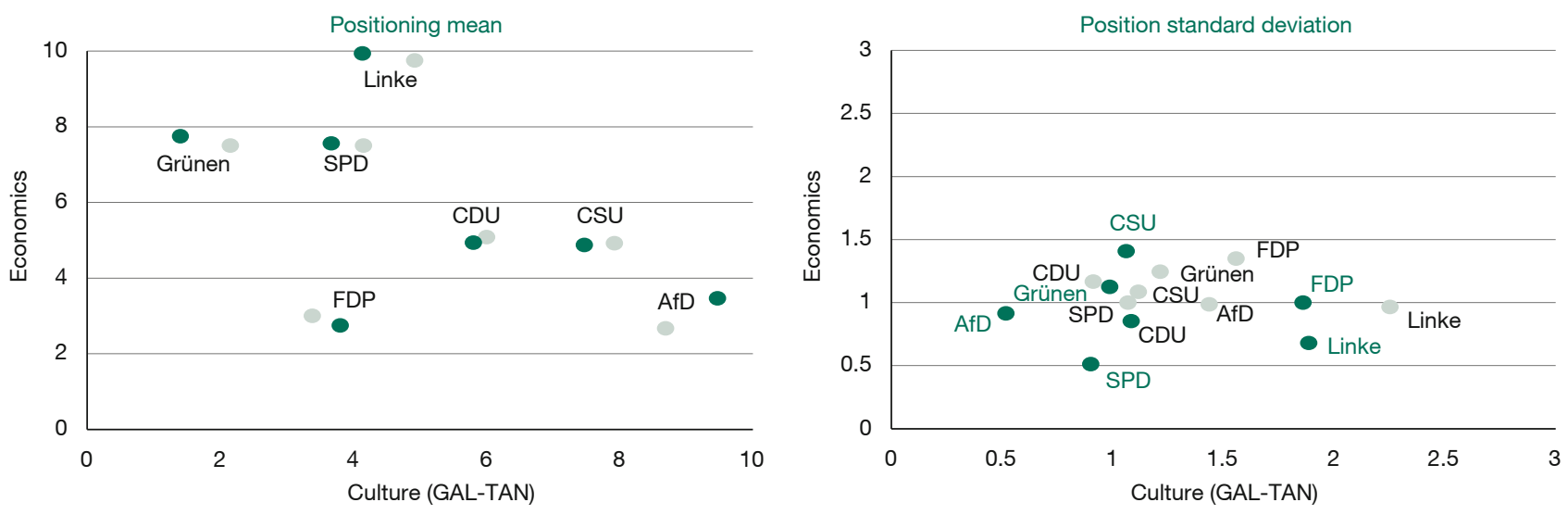

2014 - 2017

Note: For an easier graphical representation of Figure 1, the economic scale has been reversed in comparison to the original $\mathrm{CHES}$ data.

Source: Author's own calculations based on Chapel Hill Expert Survey (CHES).

and protest election motives in line with Bieber et al., ${ }^{53}$ an unweighted index of satisfaction with the established parties on an 11-point scale, an index on democracy dissatisfaction on an 11-point scale, as well as an 'Angela Merkel sympathy' index on a 5-point scale is compiled. Grouping the respondents over the two relevant periods that the AfD went through - divided by the sacking of Bernd Lucke in June 2015 - the selected GLES waves provide $4,123(7,483)$ respondents in the first (second) period of which 226 (581) claim to vote for the AfD. Rovny applies variance ratio tests of the perceived positional dispersion of different parties' voters to identify strategy blurring of PRRPs. ${ }^{54}$ Bartels simply counts the positional 'don't know' answers. ${ }^{55}$ Such analyses might deliver valuable indications; they can only be hints for strategy blurring, however. Younger parties' positions in particular might be perceived as ambiguous due to voters' lack of knowledge acquired over a longer period of time.

The GLES dataset allows for the testing of perceived party-supporter interrelation in a logit model for all respondents $i$, controlling for the perceived distance, the positioning preference and the salience in both dimensions $D$ - economics and culture. Additionally, APP and socioeconomic characteristics are controlled for. The model is run in the founding and radicalisation period $P$.

53 I. Bieber, S. Roßteutscher, P. Scherer, op. cit.

54 J. Rovny: Who emphasizes..., op. cit.

55 L.M. Bartels: Issue Voting Under Uncertainty: An Empirical Test, in: American Journal of Political Science, Vol. 30, No. 4, 1986, pp. 709728.

$$
\begin{aligned}
\operatorname{Pr}(\text { AfD support })_{i, P} \\
\\
=\beta_{P}+\beta_{\text {perceived distance } i, P, D}+\beta_{\text {preference } i, P, D}+\beta_{\text {salience } i, P, D} \\
+\beta_{\text {APP characteristics } i, P}+\beta_{\text {socio-economics } i, P}+\gamma_{\text {East }, P}+\varepsilon_{i, P}
\end{aligned}
$$

Merging the CHES expert judgements into the combined GLES waves further allows an analysis of objective partysupporter distance, finally making it possible to test for strategy blurring.

$$
\begin{aligned}
\operatorname{Pr}(\text { AfD support })_{i, P} & \\
& =\beta_{P}+\beta_{\text {objective distance i,P,D }}+\beta_{\text {preference i,P,D }}+\beta_{\text {salience i,P,D }} \\
& +\beta_{\text {APP characteristics } i, P}+\beta_{\text {socio-economics i,P }}+\gamma_{\text {East }, P}+\varepsilon_{i, P}
\end{aligned}
$$

The AfD is considered to blur its position in the economic dimension if AfD voters had dispersed welfare state preferences and would individually perceive that these preferences were met by the AfD, whereas objectively (by expert judgements) this distance was larger between other groups of party supporters and their supported party.

\section{Supply side: The AfD de-emphasises its 'right' economic positioning}

The German party system during the legislative period between 2013 and 2017 is mapped over the economic and cultural dimension based on the CHES expert judgements. The left-hand side of Figure 1 plots the arithmetic mean of all expert judgements for both dimensions in 2014 and 2017. On the cultural dimension, from libertarian/postmaterialism ('left') to traditional/authoritarian 
Figure 2

Perceived economic positioning of the German party system
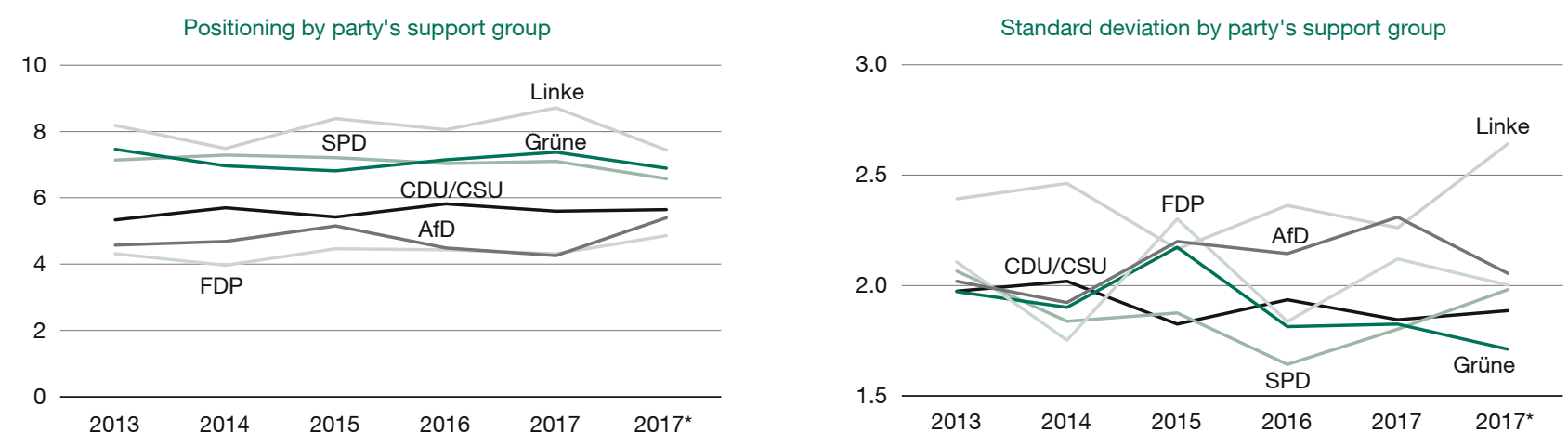

Note: *Pre- and post-election wave 2017.

So urce: Author's own calculations based on German Longitudinal Election Study (GLES).

('right'), the AfD is considered the most extreme party on the 'right' fringe of the German party system, with the Green party being its cultural antagonist on the 'left'. The AfD hence increased the range of cultural positioning in Germany and triggered a polarisation in the cultural dimension between 2014 and $2017 .{ }^{56}$ During that time, experts became exceptionally concordant in their judgements of the AfD's extreme 'right' cultural positioning.

Whereas the perceived economic positioning of parties hardly changes over the observation period, the AfD is assessed as slightly more welfare-friendly in 2017. In 2014, the party's economic policy platform is evaluated as the most anti-welfare of all German parties, and in 2017 it comes second after the liberal party FDP - providing first evidence against an economic shift to the 'left'. In general, experts agree on the parties' economic positioning. For the AfD, the standard deviation in the economic dimension even decreases after their cultural radicalisation in 2015 , and no statistically significant difference in dispersion can be found in comparison to other parties. First evidence against unidimensional positioning and strategy blurring is provided. There is no evidence for a potential welfare chauvinism positioning that could be mirrored in a rather left-leaning economic positioning in combination with a higher dispersion of expert judgements.

These findings differ significantly from the dispersion in expert judgements found in the same data source with regards to several Western European PRRPs in the eco-

56 Scoring a maximum score of 10 from 7 of 15 experts in 2017 the scale is limited in depicting a further radicalisation of the AfD. nomic dimension:57 The AfD supplies a clear 'right' economic policy platform. Its entrance into the German party system did not alter competition within the two main dimensions; It has shifted political competition away from the economic dimension, however, by polarising the cultural dimension.

\section{Demand side: AfD supporters oppose redistribution}

In order to compare the 'right' economic and cultural AfD positioning with its supporters' perception, the demand side is analysed. Figure 2 depicts the perceived economic German party positioning by the respective party supporters. Between 2013 and 2017, the comparative party assessment shows a high level of persistence. In line with expert judgements on the economic 'right', the party supporters of FDP and AfD keep changing positions. As a proxy for the clearness of positioning, again, the standard deviation reveals that the AfD's economic positioning is perceived as just as clear as other parties' stances providing further evidence against a single-issue cultural positioning.

Unfortunately, the perception analysis is based on a limited sample as it ignores respondents lacking the knowledge or confidence to assess the AfD. The share of 'don't know' answers of the electorate and AfD supporters in the two dimensions is plotted in Figure 3. Starting in 2013, around two-thirds of the electorate has refused an assessment in both dimensions. Whereas the share of refusals decreased to only $6 \%$ in the cultural dimension, in

57 A. Afonso, L. Renwald, op. cit.; K.J. Han, op. cit.; J. Rovny: Who emphasizes..., op. cit. 
Figure 3

Share of 'don't know' answers concerning the AfD's economic and cultural positioning

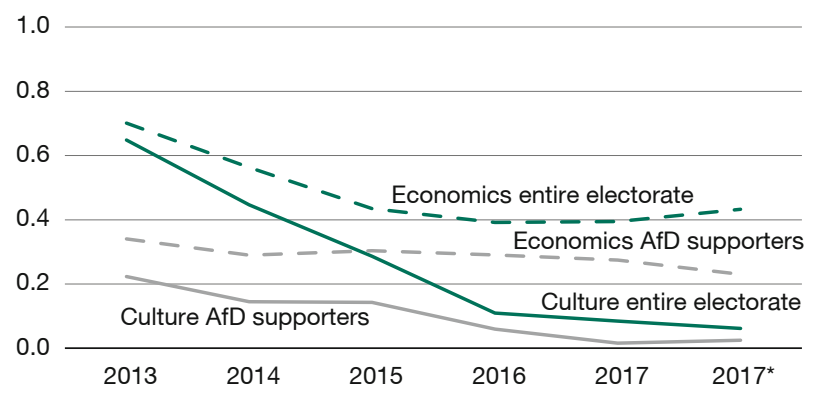

Note: *Pre- and post-election wave 2017.

Source: Author's own calculations based on German Longitudinal Election Study (GLES).

2017 it persisted at around 40\% in the economic dimension. The same trend is reflected in the AfD supporters' responses: Whereas the share of 'don't know' answers in the cultural dimension dissolved from $22 \%$ to around $2 \%$, around one-quarter of AfD supporters still 'didn't know' the party's economic positioning in 2017.

Since 'don't know' responses can indicate strategy blurring, this subgroup of AfD supporters is analysed further. ${ }^{58}$ Especially after 2015, AfD supporters who 'don't know' the party's economic positioning are poorer, less educated and have a lower self-classified social class. Their preferences for redistribution are indistinguishable from the rest of the AfD supporters, and their own economic salience is lower. Hence, in line with Rovny, ${ }^{59}$ rather than being outsmarted by a blurred positioning, it is more likely that this group of $25 \%$ of AfD supporters simply does not care about redistribution. Given their preferences, however, the party is as good of a pick for them as for the rest of the AfD party supporters.

In order to evaluate the interplay between party supporters' perceived party positioning and their own preferences, party supporters' issue preferences in the economic and cultural dimensions have to be taken into account. The author provides an overview of self-ranked class and economic policy preferences. In contrast to the slightly decreasing social class of AfD supporters over time, economic policy preferences within the different groups are not altered. In line with rational choice voting, lower social class is associated with higher preferences for redistribution. Impressively, however, the lower-class AfD support-

58 See L.M. Bartels, op. cit.

59 J. Rovny: Who emphasizes..., op. cit. ers oppose redistribution more strongly than non-AfD supporters in the (self-declared) upper middle class and even upper class. The party supporters' preferences are mirror images of the perceived party positioning and confirm evidence initially brought forward by Goerres et al.: AfD voters do not have particularly heterogeneous economic preferences - leaving little potential for strategy blurring. ${ }^{60}$ Given the comparatively low socio-economic position of the AfD electorate, the anti-redistribution preferences conflict with rational choice voting theory and traditional class-based voting. ${ }^{61}$

In the cultural dimension, AfD supporters homogeneously have radical 'right' preferences displaced from the average preferences of all other groups. The co-movement of the cultural radicalisation and the strong homogeneity of preferences are reinforced after 2015. Although the AfD polarises the German party system, this does not automatically lead to a polarisation of the electorate. Instead, the party attracts supporters with radical 'right' cultural and economic preferences who lacked political representation.

Summing up, the AfD is placed on the 'right' edge of the German party system in the dimensions of economics and culture by experts as well as by its own supporters. The above analysis of the supporters' own economic preferences shows that in line with the AfD's positional placement, its supporters have significantly more 'right' economic policy preferences than most of the electorate. This also holds for those supporters who 'don't know' the AfD's position in the economic dimension. AfD voters seem to vote against their economic interests, however, in line with their preferences in the economic dimension. Hence, first evidence is brought forward for the old winning formula.

\section{Supply meets demand: Evidence for the old winning} formula

In an attempt to shed light on the mechanism behind AfD support, a logit regression isolates the effects of the economic and cultural dimension, controlling for various socio-economic variables and measures of a protest vote. Columns 1 and 2 of Table 1 quantify the probability to support the AfD given the absolute perceived distance between a respondent's position and her or his perception of the supported party's position for the two periods analysed.

60 A. Goerres, D.C. Spies, S. Kumlin, op. cit.

61 The table providing an overview of self-ranked class and economic policy preferences is available upon request. 
Figure 4

Predictive margins logit regressions, perceived supporter-party distance, with $95 \% \mathrm{Cls}$

Table 1 Columns 1 and 2
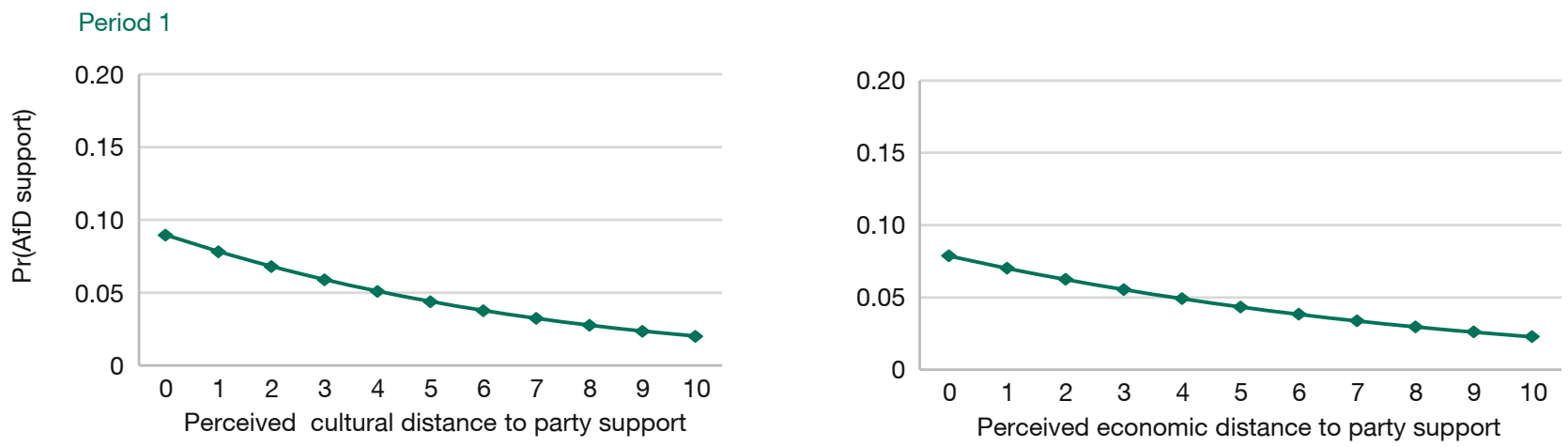

Period 2
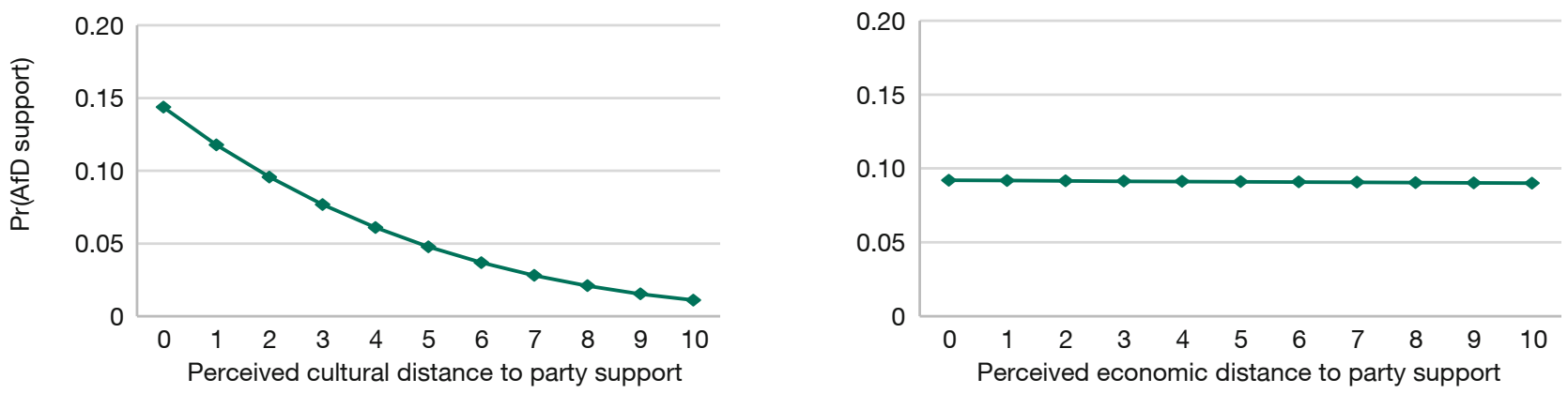

Source: Author's own calculations based on German Longitudinal Election Study (GLES).

After controlling for two-dimensional preferences, socioeconomic controls and measuring the protest vote, cultural and economic 'right' preferences increase the probability of AfD support. In the founding period, AfD supporters were more successful than other party supporters in minimising the perceived distance to their supported party in both dimensions. In the radicalisation period, they became much better in the cultural dimension and as successful as other party supporters in the economic dimension. The effect of 'right' cultural preferences is four times stronger than that of 'right' economic preferences. Nevertheless, 'right' economic preferences matter.

The socio-economic controls show the expected signs. In line with the literature, support for the AfD increased among lower-income households, married respondents as well as respondents in Eastern Germany. AfD supporters are less satisfied with the established parties and democracy, and after 2015, view Angela Merkel as less sympathetic than other party supporters. Hence, the claim that AfD supporters only care about voicing protest can be rejected. In the radicalisation period, $50 \%$ of the variation in the dependent variable is explained by the dimensional distance and preference variables as well as the included socio-economic and protest vote controls.

The regression results from columns 1 and 2 of Table 1 are shown as predictive margins in Figure 4. During the founding period, the predictive margins for AfD support decrease over an increasing perceived distance to the supported party. The coefficients of perceived cultural and economic distances are comparable. Comparing a respondent with a maximum (10) to minimum (0) perceived distance to the supported party ceteris paribus increases the probability of supporting the AfD by around five percentage points. During the radicalisation period, the perceived cultural proximity strongly gained in importance (represented by the steep negatively sloped line). In the economic dimension, AfD supporters became indistinguishable over all distances (represented by the flat line). A ceteris paribus maximum reduction of perceived cultural distance to the supported party increases the 
Figure 5

Predictive margins logit regressions, distance to expert judgements, with $95 \%$ Cls

Table 1 Columns 3 and 4
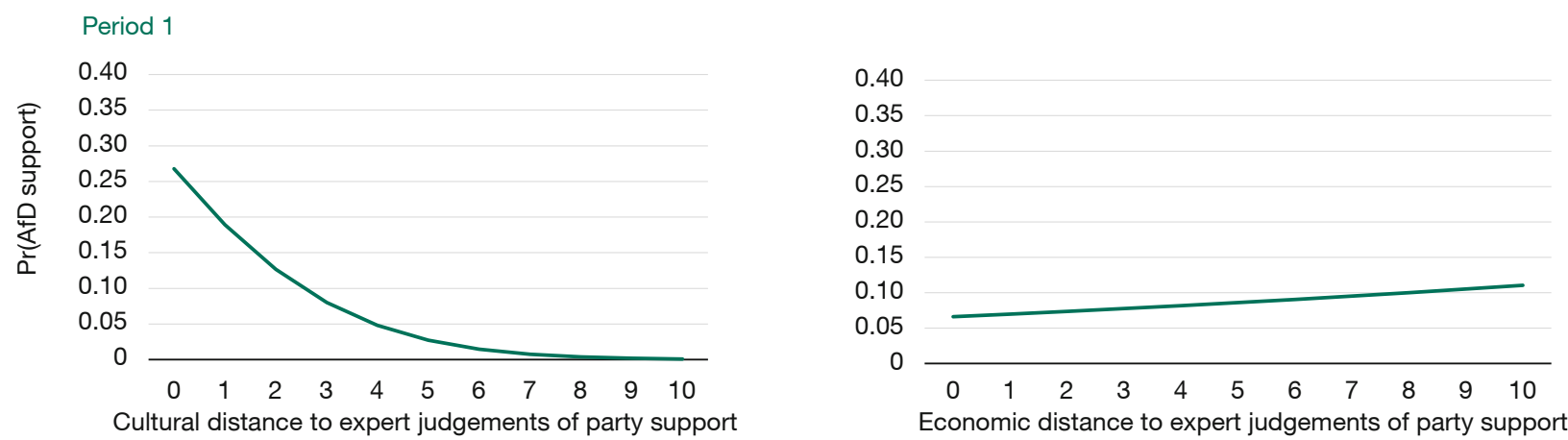

Period 2
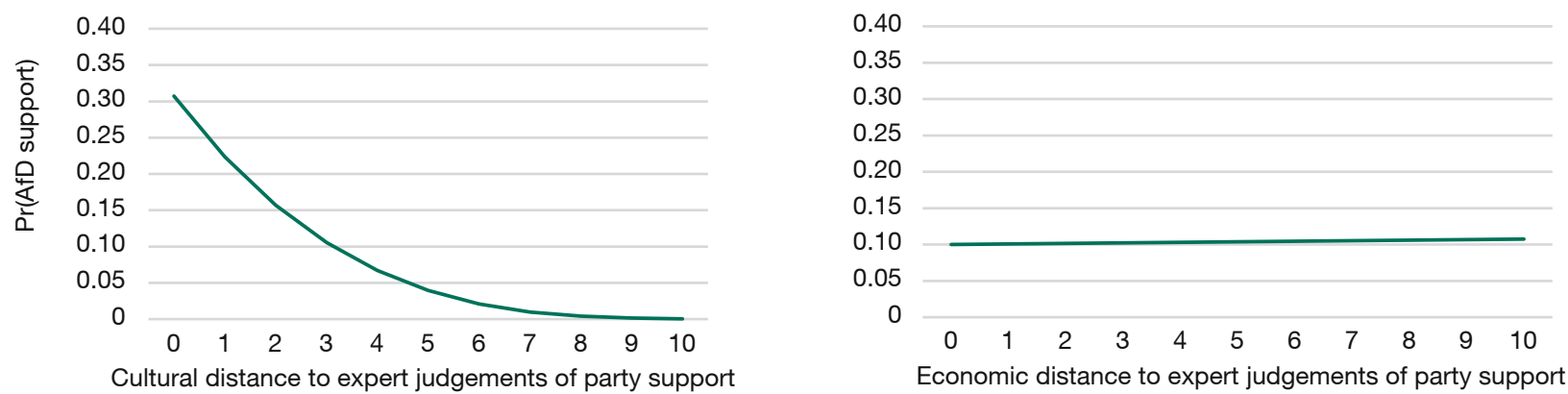

So urce: Author's own calculations based on German Longitudinal Election Study (GLES).

probability of AfD support by close to 15 percentage points.

As a final analysis of potential strategy blurring, columns 3 and 4 of Table 1 present the logit regression outputs of AfD support including the distance of respondents' dimensional preferences to the parties' objective expert assessments. Not relying on the respondents' party assessments solves the shortcoming of dropping all positional 'don't know' answers resulting in around 30\% more observations before and $20 \%$ more observations after 2015. The results are comparable with those in columns 1 and 2: Again, there is a higher probability for respondents with more 'right' preferences in the economic and cultural dimension to support the AfD - with the latter effect being much stronger than the former. Regarding the distance of AfD supporters' preferences to positional expert judgements, AfD supporters are characterised by a distinctive cultural proximity to their party. Importantly, the economic objective distance became indistinguishable from other party supporters during the radicalisation period. In the second period, the results explain over $60 \%$ of the variation in the dependent variable.

Figure 5 shows the logit regression results reported in columns 3 and 4 of Table 1 as predictive margins. A higher cultural proximity to expert judgements was a strong indicator of AfD support already during the party's founding. From a medium distance (5) to a minimum distance (0), the respective probability increased by around 20 percentage points before and by 25 percentage points after 2015. The proximity of AfD's expert placements in the cultural dimension and the AfD supporters' homogeneous cultural preferences are exceptional. The increasing objective distance in the economic dimension in the founding period could be explained by the integration of respondents with little economic interest ('don't know' or 'don't care'). As AfD supporters become indistinguishable in their economic party-supporter distance, there is very little interpretational room for a need of economic strategy blurring. Even during the radicalisation period, AfD 
Table 1

Logit regression AfD voting intentions, perceived and objective distance

\begin{tabular}{|c|c|c|c|c|}
\hline & (1) & (2) & (3) & (4) \\
\hline Variables & Period 1 & Period 2 & Period 1 & Period 2 \\
\hline $\begin{array}{l}\text { Perceived economic } \\
\text { distance to support } \\
\text { party }\end{array}$ & $\begin{array}{l}-0.167^{\star} \\
(0.065)\end{array}$ & $\begin{array}{l}-0.005 \\
(0.045)\end{array}$ & & \\
\hline $\begin{array}{l}\text { Perceived cultural } \\
\text { distance to support } \\
\text { party }\end{array}$ & $\begin{array}{l}-0.206^{\star} \\
(0.057)\end{array}$ & $\begin{array}{l}-0.428^{* * *} \\
(0.056)\end{array}$ & & \\
\hline $\begin{array}{l}\text { Ecopnomic distance } \\
\text { to expert judgements } \\
\text { of support party }\end{array}$ & & & $\begin{array}{l}0.153^{\star *} \\
(0.060)\end{array}$ & $\begin{array}{c}0.035 \\
(0.046)\end{array}$ \\
\hline $\begin{array}{l}\text { Cultural distance to } \\
\text { expert judgements of } \\
\text { support party }\end{array}$ & & & $\begin{array}{l}-0.786^{\star \star \star} \\
(0.131)\end{array}$ & $\begin{array}{l}-1.019^{\star \star \star} \\
(0.085)\end{array}$ \\
\hline $\begin{array}{l}\text { Own economic } \\
\text { position }\end{array}$ & $\begin{array}{l}-0.238^{\star \star \star} \\
(0.055)\end{array}$ & $\begin{array}{l}-0.104^{\star \star \star} \\
(0.036)\end{array}$ & $\begin{array}{l}-0.160^{\star \star \star} \\
(0.040)\end{array}$ & $\begin{array}{l}-0.142^{\star \star \star} \\
(0.033)\end{array}$ \\
\hline Own cultural position & $\begin{array}{l}0.224^{\star \star \star} \\
(0.056)\end{array}$ & $\begin{array}{l}0.415^{\star \star *} \\
(0.050)\end{array}$ & $\begin{array}{l}0.483^{\star \star \star} \\
(0.105)\end{array}$ & $\begin{array}{l}0.703^{\star \star \star} \\
(0.069)\end{array}$ \\
\hline $\begin{array}{l}\text { Party satisfaction } \\
\text { index }\end{array}$ & $\begin{array}{l}-0.555^{\star \star \star} \\
(0.081)\end{array}$ & $\begin{array}{l}-0.423^{\star \star \star} \\
(0.060)\end{array}$ & $\begin{array}{l}-0.360^{\star \star \star} \\
(0.065)\end{array}$ & $\begin{array}{l}-0.291^{\star \star \star} \\
(0.058)\end{array}$ \\
\hline $\begin{array}{l}\text { Democracy dissatis- } \\
\text { faction index }\end{array}$ & $\begin{array}{l}0.726^{\star \star \star} \\
(0.150)\end{array}$ & $\begin{array}{l}0.467^{\star \star \star} \\
(0.100)\end{array}$ & $\begin{array}{l}0.690^{\star \star \star} \\
(0.125)\end{array}$ & $\begin{array}{l}0.474^{\star \star \star} \\
(0.089)\end{array}$ \\
\hline $\begin{array}{l}\text { Merkel sympathy } \\
\text { index }\end{array}$ & $\begin{array}{l}-0.049 \\
(0.035)\end{array}$ & $\begin{array}{l}-0.211^{\star \star \star} \\
(0.029)\end{array}$ & $\begin{array}{l}-0.108^{\star \star \star} \\
(0.034)\end{array}$ & $\begin{array}{l}-0.291^{\star \star *} \\
(0.029)\end{array}$ \\
\hline $\begin{array}{l}\text { Socio-economic } \\
\text { controls }\end{array}$ & $\checkmark$ & $\checkmark$ & $\checkmark$ & $\checkmark$ \\
\hline $\begin{array}{l}\text { East Germany } \\
\text { Dummy }\end{array}$ & $\checkmark$ & $\checkmark$ & $\checkmark$ & $\checkmark$ \\
\hline Observations & 1,959 & 3,439 & 2,507 & 4,055 \\
\hline Adjusted R-squared & 0.301 & 0.489 & 0.369 & 0.624 \\
\hline
\end{tabular}

Notes: Splitting the sample into East and West Germany and limiting the sample to pre- and post-election study in order to apply sample weights does not qualitatively alter the results. Further regression outputs may be provided upon request.

supporters are clearly not tricked into endorsing the party due to a misinterpretation of the party's economic positioning. Since 'right' economic and cultural preferences remain significant after controlling for protest support, the AfD gets support because of and not despite its issue positioning.

\section{Conclusions}

The regression analysis reveals that cultural and economic 'right' preferences indicate higher chances of support for the AfD - albeit the effect of the cultural dimension is four times stronger. Even after 2015, the perceived and objective economic proximity has mattered just as much for AfD supporters as for supporters of other parties. The results hold for Western and Eastern Germany alike.

In contrast to providing evidence for strategy blurring, this analysis stresses the AfD's winning formula of a strongly emphasised 'right' cultural and a less emphasised 'right' economic positioning, while at the same time enabling its supporters to protest. AfD supporters' systemic discontentment does not reduce them to issue-free party followers as even AfD supporters who 'don't know' the party's economic positioning are well represented. For its political competitors, this clearly means that during the 20132017 legislative period, strong redistribution and economic policy for social justice had little chance of convincing AfD supporters. A feasible AfD competitor supporting redistribution and coming along with a credible anti-system appeal or 'right' cultural policies would still struggle to convince AfD supporters. As none of the established parties in Germany can credibly adopt such a positioning and the AfD has left behind its pure protest character, the party is unlikely to be challenged from within the existing party system.

Nevertheless, there is a chance that the party may change its positioning away from its current winning formula towards a more 'left' economic policy offer. This could particularly happen once far-right faction leader Hoecke finally manages to marginalise the formerly influential liberal economists within the party leadership and to build up a 'party of social justice'. ${ }^{2}$ Whether such a shift could improve the parties' electoral success is questionable given the findings of the present study. In Western Europe the AfD's winning formula directed also at supporters with low income positions remains an exception. However, a similar set of political attitudes conflicting with economic interests has been discussed in the 'What's the matter with Kansas' debate:63 A strict refusal of state interventions including the welfare state and climate change regulations can be found among radical supporters of the Republican Party who hold low socio-economic positions in different regions of the USA. ${ }^{64}$

62 R. Hank, op. cit.

63 T. Frank: What's the matter with Kansas?: How conservatives won the heart of America, New York 2004, Henry Holt and Co.

64 A.R. Hochschild: Strangers in their own land: anger and mourning on the American right, New York 2016, The New Press. 